Acta Horticulturae et Regiotecturae - Special Issue

Nitra, Slovaca Universitas Agriculturae Nitriae, 2021, pp. 8-11

\title{
AN IRRIGATION HOMOGENITY ASSESSMENT OF A VARIABLE RATE SPRINKLER IRRIGATION
}

\author{
Andrea SZABÓ*, János TAMÁS, Attila NAGY \\ University of Debrecen, Hungary
}

\begin{abstract}
Nowadays, the development of irrigation is increasingly recognized as a necessary factor in agriculture, primarily because of global warming. Depending on the field conditions, the most commonly used method is sprinkler irrigation. The spray uniformity of sprinklers installed on the field irrigation equipment can be characterized by the Christiansen-uniformity coefficient (CUc\%) and the distribution uniformity coefficient (DU\%). Our investigations were carried out on the lateral moving irrigation equipment of University of Debrecen, Institutes for Agricultural Research and Educational Farm and Nyírbátor's company in Hungary in 2019. Variable rate irrigation (VRI) is used in Nyírbátor. In contrast, the VRI has given positive results, making an irrigation equipment with the VRI a safer and more uniform method than a conventional linear irrigation equipment.
\end{abstract}

Keywords: irrigation, Christiansen-uniformity, distribution uniformity, crop

The Intergovernmental Panel on Climate Change concluded in its second assessment report that global climate change will increase the frequency of floods and droughts. In the future, the increase of water demand will be influenced by a number of factors, such as urbanization, the growth of irrigated areas and intensive agriculture (Iglesias et al., 2010; Kellis, Kalavrouziotis, Gikas, 2013). There are 324 million hectares of irrigated land in the world, covering $21 \%$ of the world's total production area, with $61 \%$ of the harvested crops coming only from various cereals (FAO, 2016). The average annual precipitation in Hungary is $0.5-0.7 \mathrm{~m}$. However, the annual precipitation shows a decreasing trend (MET, 2019). The changing weather in recent years is also a problem for agriculture (Szalai, 2009; Jolánkai et al., 2018). That is why the irrigation is now considered an increasingly necessary factor. Nevertheless, due to lack of irrigation, the yield averages fluctuate every year. Based on the available water resources and water management options, approximately 400,000 hectares of land in Hungary could be irrigated instead of the current 100.00 ha (Nemzeti Vízstratégia, 2017). In order to ensure the stability of crop safety, it would be necessary to apply $0.1-0.2 \mathrm{~m}$ of irrigation water/year, which means $1.000-2.000 \mathrm{~m}^{3} \cdot \mathrm{ha}^{-1}$ of water for the field. After assessing the needs of the plants, a decision must be made to use a proper irrigation method (Smith, Baillie, 2009). Depending on the field conditions, the most common methods of irrigation within rainwater irrigation are linear and winder drum irrigation. The precision irrigation is when a precise water application minimizes the adverse effects on the environment, while meeting the needs of the individual plants (Raine et al., 2007), which is now identified as a 'variable rate irrigation' (VRI). When using the VRI, some important information can be integrated into the irrigation, for example soil parameters, topographic maps and data of the plant to be irrigated (Boluwade, Madramootoo, Yari, 2016; Colaizzi et al., 2017; Yari et al., 2017). In our research, we aimed to compare the irrigation homogeneity of a linear irrigation equipment with the VRI controlled linear irrigation equipment, revealing the ratio of underserved and overirrigated areas. The surveys were conducted under field conditions on sweet corn.

\section{Material and method}

The field surveys were carried out at the University of Debrecen, Institutes for Agricultural Research and Educational Farm and in the arable areas of Nyírbátor's company in Hungary in July and August in 2019 on different types of linear irrigation equipment (Table 1).

In the course of the research, we evaluated the spray uniformity of the conventional and linear irrigation equipments with the VRI, as well as the proportion of under- and over-irrigated areas. Three field surveys were conducted in which the precipitation meters were placed under the irrigation equipment. The measuring vessels were placed in a $4 \times 4$ grid at every $5 \mathrm{~m}$ to $0.3 \mathrm{~m}$ and $1.5 \mathrm{~m}$ height in the maize row spacing at each measurement time. The first two measurements were used to examine the standard deviation of the utilized water by the conventional linear irrigation equipment and the third measurement was used to examine the uniformity of spraying and interception of the VRI. The corn was $0.5 \mathrm{~m}$ high for all three measurements. Conventional linear water was applied with a uniform linear

Contact address: Andrea Szabó, University of Debrecen, Faculty of Agricultural and Food Sciences and Environmental Management, Institute of Water and Environmental Management, J +36 5050 84 44/880 12; e-mail: szabo.andrea@agr.unideb.hu, 
Table 1

The surveyed irrigation equipments

\begin{tabular}{|l||c|c|}
\hline \multicolumn{1}{|l||}{ Location } & $\begin{array}{c}\text { University of Debrecen, Institutes for } \\
\text { Agricultural Research and Educational Farm }\end{array}$ & Bátortrade Kft in Nyírbátor \\
\hline Irrigation equipments & Linear irrigation equipment & Precision linear irrigation equipment with VRI \\
\hline Type of the irrigation equipments & $\begin{array}{c}\text { Valley } 8120 \text { universal irrigation equipment } \\
\text { with underground induction control }\end{array}$ & Reinke E2060PL reversible linear \\
\hline Type of the nozzles & Seninger & $\begin{array}{c}\text { Rotator Pivot Sprinkler (Nelson Irrigation } \\
\text { Corporation) }\end{array}$ \\
\hline
\end{tabular}

velocity of $20 \mathrm{~m} \cdot \mathrm{h}^{-1}$ at the same water pressure and in the case of the VRI, with $10 \cdot 10^{-3} \mathrm{~m}$ irrigation water application. There was complete wind silence at the time of the measurements. The spray uniformity was calculated from the data of the amount of irrigation water $\left(1 \cdot 10^{-3}\right)$ applied to the rain meters. To determine the uniformity values of the nozzles, we used the Christiansen-uniformity coefficient (CUc \%) (1) calculated on the basis of the water volumes of the collecting vessels placed at a height of $1.5 \mathrm{~m}$ (Karmeli, 1978; Topak et al., 2005) (1). The other really important factor is the distribution uniformity (DU\%) (2), which is particularly sensitive to underwatering, was calculated to determine the uniformity of a water application (Kruse, 1978):

$$
C U_{C}=100\left[1-\frac{\sum_{i=1}^{n}\left|V_{i}-\bar{V}\right|}{\sum_{i=1}^{n} V_{i}}\right]
$$

where:

$$
\begin{array}{ll}
\sum\left|V_{i}-\bar{V}\right| & -\begin{array}{l}
\text { sum of the absolute deviations of the individual } \\
\text { measurements in relation to the mean }
\end{array} \\
\bar{V} & - \text { average of all measurements } \\
V_{i} & - \text { individual measurement data } \\
n & - \text { number of measuring points }
\end{array}
$$

$$
D U \%=100\left(\frac{\overline{X_{i 25 \%}}}{\overline{X_{i}}}\right)
$$

where:

$X_{i 25 \%}$ - the average of the water covering of the driest quarter

$X_{i} \quad$ - the average water covering of the whole area

In addition to the calculation of uniformity factors, the spatial distribution of the application was also examined in order to delimit the under- and over-irrigated areas. The limit value of underwatering was calculated as the median - (median-minimum) - CUc\% (3) for the amount of the applied irrigation water. The limit value of over-irrigation was calculated as the median + (maximum - median) . CUc\% (4) for the amount of the applied irrigation water. The distribution of an irrigation water application was analysed in a Surfer program.

We have also examined the gradual transition between the different irrigation sectors. During the measurements, 15 rain gauges per meter were placed at a height of $1.5 \mathrm{~m}$. In the case of the conventional linear irrigation, its speed was reduced to $10 \mathrm{~m} \cdot \mathrm{h}^{-1}$ by increasing the amount of the applied irrigation water. Concerning the VRI, the water application was increased to $20 \cdot 10^{-3}$. The development of the amount of interception was calculated on the basis of the linear and conventional results with the VRI at $0.5 \mathrm{~m}$ high maize stands with the water volumes of the measuring vessels placed at a height of $0.3 \mathrm{~m}$.

\section{Results and discussion}

\section{Christiansen's uniformity factor and the distribution uniformity results}

The average amount of irrigation water collected in the rain gauges placed at a height of $1.5 \mathrm{~m}$ was $14.5 \pm 4.44 \cdot 10^{-3}$ in the case of the conventional linear irrigation system. The irrigation uniformity of the nozzles was CUc\% 75.43\% and DU\% 74.14\%. The CUc\% value must reach a minimum of $84 \%$ and the deviation uniformity in practice and the minimum value of homogeneity is $80 \%$ DU\% (Irmak et al., 2011). Since the results do not reach the minimum values for homogenous irrigation, the application of linear water is not uniform. The use of the nozzles resulting from the older equipment can be the reason for the poor uniformity. The average amount of irrigation water collected in the rain gauges placed at a height of $1.5 \mathrm{~m}$ was $10.03 \pm 0.64 \cdot 10^{-3}$ in the case of the VRI. The CUc\% calculated from the data of the applied water was $95.25 \%$ high and the DU\% showed $90.97 \%$ for the VRI, which means that the irrigation is homogenous. In addition, the VRI had smaller standard deviation than the conventional one without the VRI, which also suggests that the water application is more homogeneous and uniform in the case of the VRI. The spatial distribution study also reveals a significant difference in irrigation uniformity between two different linear technologies (Figure 1).

When we used the conventional linear irrigation equipment, the under-irrigated area was $46.15 \mathrm{~m}^{2}$ which is $20.5 \%$ of the total irrigated area. The over-irrigated part is $7.45 \mathrm{~m}^{2}$ which is $3.3 \%$ of the total area. In contrast, when the VRI was used, the under-irrigated area was $8.55 \mathrm{~m}^{2}$ which is $3.8 \%$ of the total irrigated area, while the over-irrigated area was $0.007 \mathrm{~m}^{2}$ which is $0.03 \%$ of the total area.

\section{Evaluation of the gradualness of transition between the irrigation sectors}

As a pilot study for the conversion of the water applications between the sectors, we set up 15 water collector dishes in one line in one meter distances. It is important that the result represents the increasing water application values of a single nozzle. In the case of the conventional linear system, we changed the speed of the irrigation equipment without changing the water pressure. Thus, the rate of a specific 


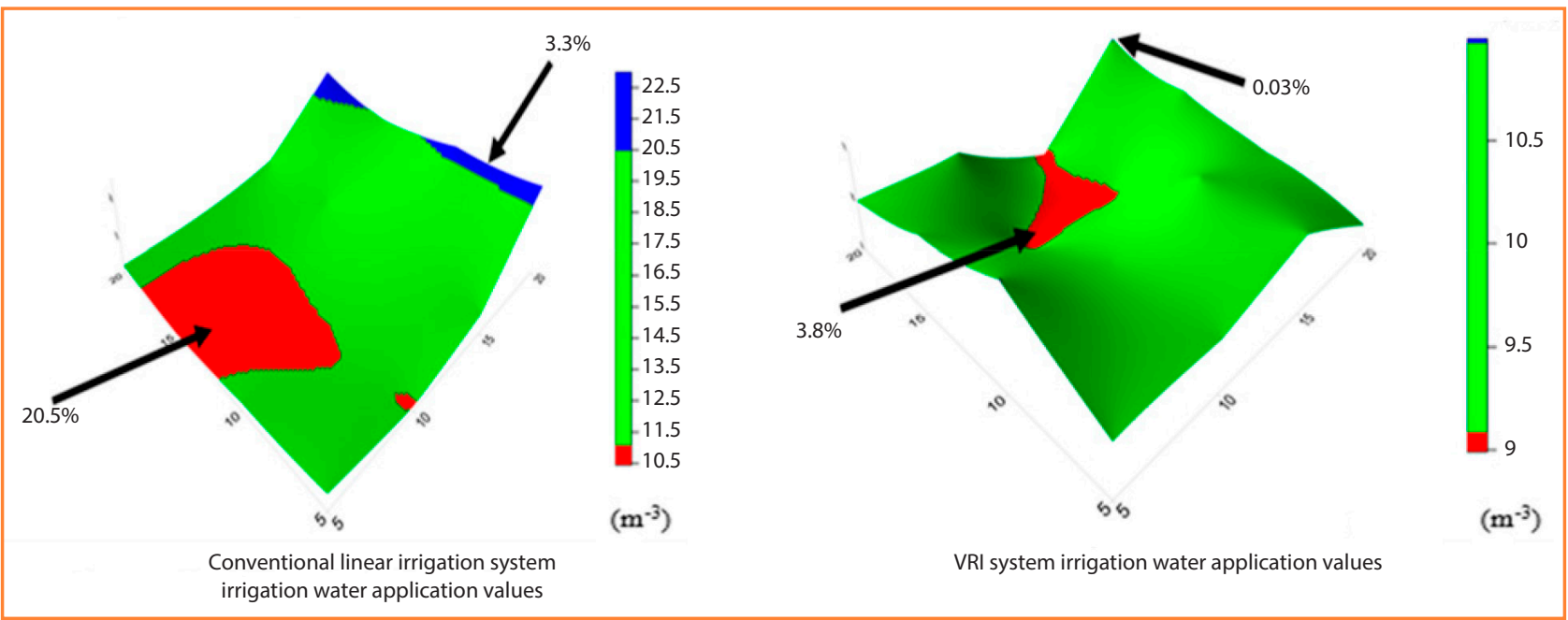

Figure 1 Spatial distribution of the irrigation water application

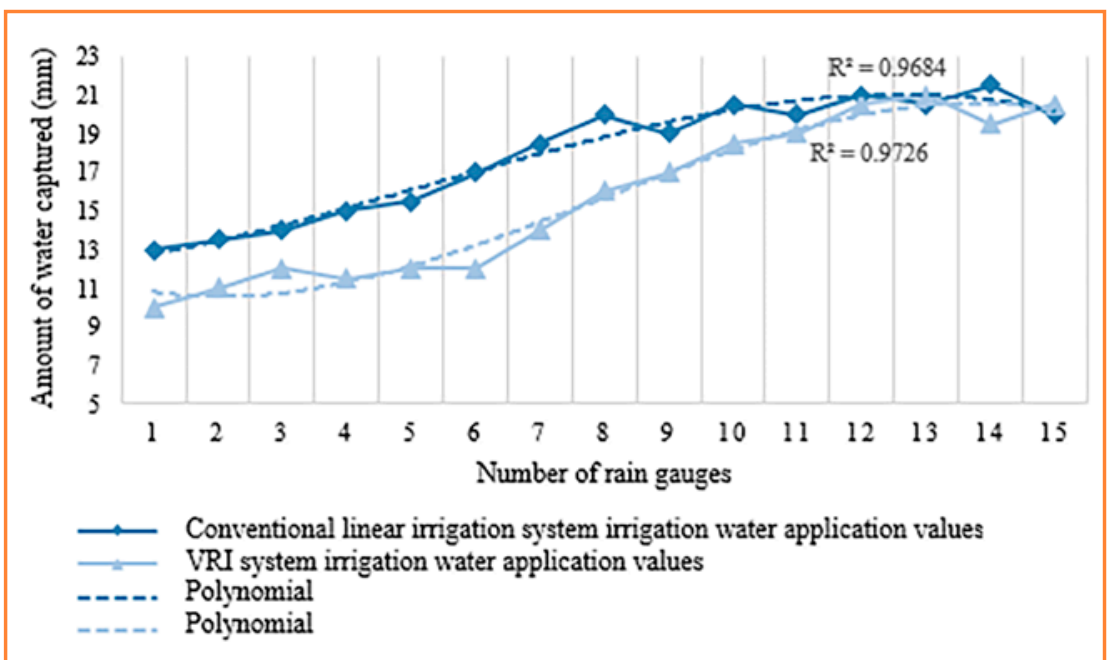

Figure 2 Irrigation water application between sectors

water application was modified. The amount of the applied irrigation water was regulated at the nozzle level in the VRI. In the case of the conventional linear system, the speed of the irrigation equipment was reduced from $20 \mathrm{~m} \cdot \mathrm{h}^{-1}$ to $10 \mathrm{~m} \cdot \mathrm{h}^{-1}$. We increased the rate of the water application from $10 \cdot 10^{-3}$ to $20 \cdot 10^{-3}$ in the case of the VRI. The uniformity and gradualness of the switching between the sectors was evaluated with a polynomial function. Based on the deterministic coefficients, both the conventional and the VRI have a sufficiently smooth transition between the sectors $\left(R^{2}=0.968\right.$ and $R^{2}=0.973$ ) (Figure 2).

\section{Evaluation of the effect of interception of the irrigation distribution uniformity}

The interception of the $0.5 \mathrm{~m}$ high maize was calculated on the basis of the water collector dishes placed at a height of $0.3 \mathrm{~m}$. We did not find a significant difference in the interception between the different linear technologies: the degree of interception ranged from 2.5 to 4.69 . $10^{-3}$ in the area, with an average value of $3.42 \cdot 10^{-3}$. There is no significant change in the irrigation uniformity based on Christiansen-uniformity coefficient between the uniformity with and without an interception. In the case of the conventional linear system, the Christiansen uniformity coefficient (ICUc\% 74.93\%) is just $0.66 \%$ smaller than the interception- free values, while for the VRI, the Christiansen-uniformity coefficient is ICUC\% $93.64 \%$, which is $1.69 \%$ below the coefficient calculated under the interception-free circumstances. In contrast, more differences were found between the conventional and the VRI in the case of changes in the DU values. The DU value with an interception is $58.05 \%$, which is $21.7 \%$ smaller than the DU without an interception, while for the VRI, the decrease is only $4.06 \%$. The DU is a more sensitive indicator of under-irrigation than the $\mathrm{CU}$, because it compares the driest quarter water application to the average application. Though the distribution of interception is considered to be homogeneous, the effect of interception is more significant on the under-irrigated sites $(20.5 \%$ of the studied area) with 9-11.5 $\cdot 10^{-3}$ water utilization compared to the areas with an average $14.5 \cdot 10^{-3}$ water application. The 3.42 . $10^{-3}$ interception represents $30-36 \%$ of the applied irrigation water in the driest area and in those sites where the water application was average $\left(14.5 \cdot 10^{-3}\right)$, the interception is only $24 \%$ of the applied water amount. Therefore, besides the fact that less irrigation water was applied on the under-irrigated areas, the rate of the net irrigation water was smaller as well.

\section{Conclusion}

The lack of natural precipitation can be compensated primarily with irrigation to reduce yield fluctuations, increase yields and improve crop quality. The application of homogeneous and 
adequate irrigation water in a field area is important in several aspects. Improper application of water can lead to the deterioration of the production area, pesticides can leach out of the soil as well as deterioration of the soil structure and the formation of salinisation can occur. For this reason, it is important to use an irrigation system that is suitable for applying safe and stable homogeneous irrigation water. Our research results, the application uniformity of the VRI, are homogeneous, while in the case of the conventional linear system, a significant heterogeneity can be observed. Use of the VRI in a long-term horizon ensures a good quality of field conditions and provides a solid basis for the design and development of precise agriculture as well as precise irrigation technologies. Moreover, the use of the VRI reduces the phenomenon of under- and over-irrigated areas.

\section{Acknowledgements}

The research is funded by TKP2020-IKA-04 project. Project no. TKP2020-IKA-04 has been implemented with the support provided from the National Research, Development and Innovation Fund of Hungary, financed under the 20204.1.1-TKP2020 funding scheme.

\section{References}

Boluwade, A., Madramootoo, C., Yari, A. (2016). Application of unsupervised clustering techniques for management zone delineation: Case study of variable rate irrigation in Southern Alberta, Canada. Journal of Irrigation and Drainage Engineering, 142(1), 1-8.

Colaizzi, P. D., O'Shaughnessy, S. A., Evett, S. R., Mounce, R. B. (2017). Crop evapotranspiration calculation using infrared thermometers aboard center pivots. Agricultural Water Management, (187), 173-189.

FAO (2016). AQUASTAT website. http://www.fao.org/nr/water/ aquastat/didyouknow/index3.stm Query date: 2018.12.

Iglesias, R., Ortega, E., Batanero, G., Quintas, L. (2010). Water reuse in Spain: data overview and costs estimation of suitable treatment trains. Desalination 263, 1-10.
Irmak, S., Odhiambo, O. L., Kranz, L. W., Eisenhauer, E. D. (2011). Irrigation Efficiency and Uniformity, and Crop Water Use Efficiency. Biological Systems Engineering: Papers and Publications, (451) 8.

Jolánkai, M., Kassai, M. K., Tarnawa, Á., Pósa, B., Birkás, M. (2018). Impact of precipitation and temperature on the grain and protein yield of wheat (Triticum aestivum L) varieties. Időjárás, 122(1), 31-40. Karmeli, D. (1978). Estimating sprinkler distribution pattern using linear regression. Transactions of the ASAE, (21), 682-686.

Kellis, M., Kalavrouziotis, I. K., Gikas, P. (2013). Review of wastewater reuse in the Mediterranean countries, focusing on regulations and policies for municipal and industrial applications. Glob. Nest J., 15, 333-350.

Kruse, E. G. (1978). Describing Irrigation Efficiency and Uniformity. Journal of the Irrigation and Drainage Division, 104(1), 35-41.

MET (2019). website. https://www.met.hu/eghajlat/ magyarorszag eghajlata/altalanos eghajlati jellemzes/csapadek/ Query date: 2019.07.

Nemzeti Vízstratégia (2017). Nemzeti Vízstratégia (Kvassay Jenő Terv). In eng.: National Water Strategy (Jenő Kvassay Plan) (140p.).

Raine, S. R., Meyer, W. S., Rassam, D. W., Hutson, J. L., Cook, J. F. (2007). Soil-water and solute movement under precision irrigation: Knowledge gaps for managing sustainable root zones. Irrigation Science, 26(1), 91-100.

Smith, R. J., Baillie, J. N. (2009). Defining precision irrigation: A new approach to irrigation management. National Centre for Engineering in Agriculture and Cooperative Research Centre for Irrigation Futures (pp. 18-21).

Szalai, S. (2009). Drought Tendencies in Hungary and its Impacts on the Agricultural Production. Cereal Research Communications, (37), 501-504.

Topak, R., Suheri, S., Ciftci, N., Acar, B. (2005). Performance evaluation of sprinkler irrigation in a semi-arid area. Pakistan Journal of Biological Sciences, (8), 97-103.

Yari, A., Madramootoo, A. C., Woods, A., Shelley-Adamchuk, I. V. (2017). Performance Evaluation of Constant Versus Variable Rate Irrigation. Irrigation and Drainage, 66(4), 501- 509. 